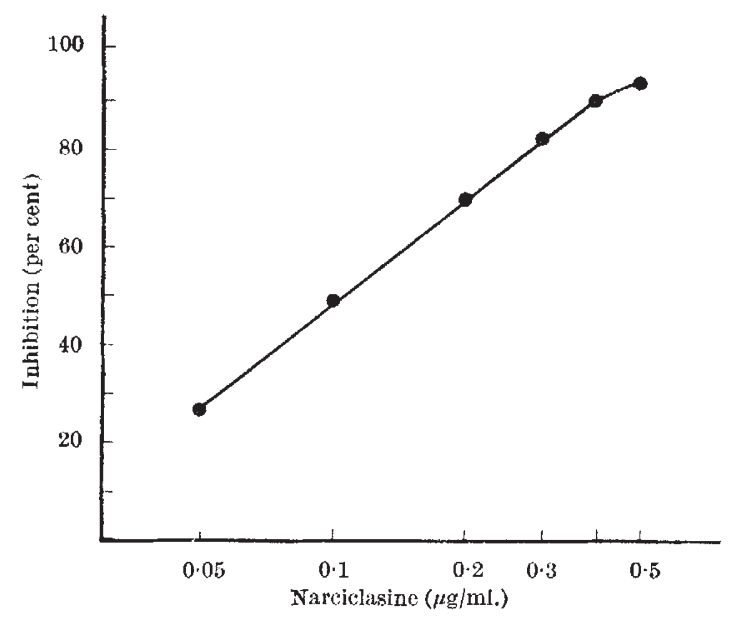

H'ig. 2. Linear relationship between the pcr cent inhibition of growth of the lateral radicles and the log of concentration of narcicjasine.

at very low doses and the subeutaneous routo appeared the most effective. A colchicino-]iko effect was present at $0.5 \mathrm{mg} / \mathrm{kg}$. $\Lambda$ drastic decrease of the number of mitoses was seen $2 \mathrm{~h}$ after injection of $0.9 \mathrm{mg} / \mathrm{kg}$, and after $4 \mathrm{~h}$ no more mitotic figures could be dotected. As tho dosage was increased tho mitoses disappeared more rapidly and disrupted cells with globular clumps of chromatin appeared more frequently.

Mitoses reappeared sometimes at $18 \mathrm{~h}$ after the injection according to the dosage and the route of adminis. tration used. From an analysis of its antimitotic effect, "narciclasino" scems to act essentially as a metaphasic or a preprophasic poison and to have a mitoclasic activity especially at high doses. An $L D_{50}$ of $5 \mathrm{mg} / \mathrm{kg}$ has been determined in mice by subcutaneous injection.

Centro Studio Tumori,

G. Ceriotiti

Busto Arsizio, Italy.

${ }^{1}$ H'itzgerald, D. B., Hartwcll, J, L., and Leiter, J., J. Nat. Cancer Inst., 20

"Ceriott1, Q., Giorn. Botan., 73, 139 (1066).

"Piozzi, F., Fuganti, C., Mandelli, R., and Ceriotti, G., Tetrahedron Lell. (in the press).

\section{Phagocytosis in Mammalian Hair}

ON the basis of electron microscope investigations of the human hair follicle Birbeck and Mercer ${ }^{1}$ suggested that pigment granules enter the cortical cells by phagocytosis. Swift ${ }^{2}$ gave support to this suggestion by illustrating tho close association between pigment granules and cortical cell membranes in human hair. During recent investigations on a range of less common animal hairs we have obtained much additional evidence in support of the view that phagocytosis is responsible for the ingestation of pigment granules into cortical cells.

Birbeck and Mercer ${ }^{1}$ stated that they had never observed granules in the cuticular cells, although Swift (porsonal communication) has only rarely seen single granules in the cuticle of human hair. My work on guanaco and vicuna hair (two species of Llama), and swamp wallaby hair, has revealed the not infrequent presence of pigment granules within cuticular cells. To my knowledge this has not been previously reported.

Hairs were first reduced with a 0.5 molar solution of thioglyeollic acid and then treated with a 0.05 molar solution of silver nitrate in accordance with the method of Dobb et al. ${ }^{3-5}$. Treated fibres were embedded in 'Araldite', sectioned on an ultratome, collected from deionized water on to uncoated 'Now 200' grids, and examined in an electron microscope.

While single pigxnent granules have failly frequently been observed in cuticular cells, the most intoresting examplo is shown in Fig. 1, where a cluster of small gran.

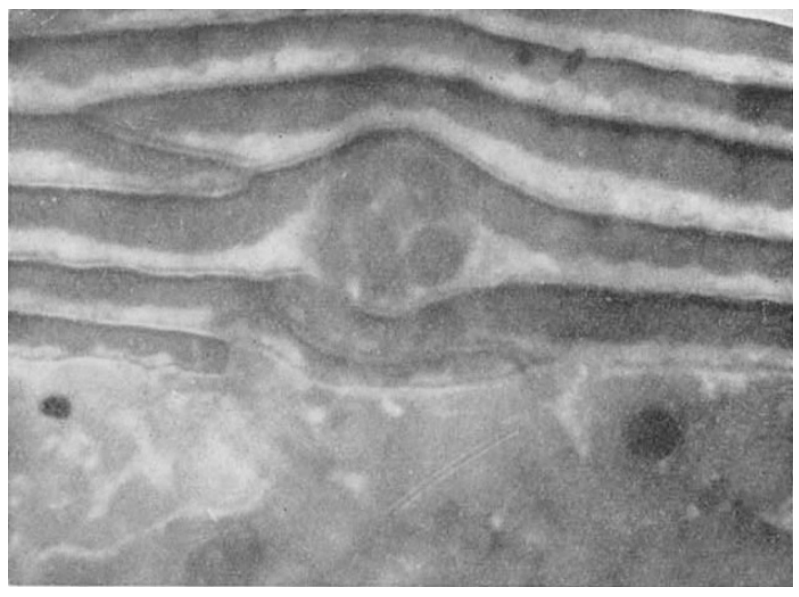

Fig. 1. Thin section of the cuticle of swamp wallaby hair (siiver treated, $\times 24,000)$.

ules is clearly ovident in a cuticular cell of swamp wallaby hair. Guanaco hair also occasionally has clusters of this type, but so far the greatcst incidence of theso pigment inclusions has been found in the swamp wallaby hair, which also shows excessive pigmentation of the cortical cells, not only in large clusters, but also in strings, which often contain more than twenty granules.

In the cortex of swamp wallaby hair, in particular, there is ample evidence to support the view that a phagocytotic process is used to facilitate the entry of pigment granules into cortical colls, because there are numerous examples of the association between pigment granules and cortical cell membranes; and it is suggested that phagocytosis is also responsible for the inclusion of pigment granules in the euticular cells.

The fact that pigment granules are rarely observed in cuticular cells of human hair, but are frequently found in the other hairs studicd, suggests that differences exist between tho various hairs in some of the stages of fibre growth in the region of the papilla. This point will require further invostigation.

I thank Dr. J. Sikorski for his advice and encouragement in this work.

Dopartment of Textiles,

I. P. S. PIPER

Derby and District College of Technology.

${ }^{1}$ Birbeck, M. S. C., and Mercer, L. Il., J. Biophys. Biochem. Cytol., 3, 203 (1956). ${ }^{2}$ Swift, J. A., Nature, 203, $976(1964)$.

${ }^{3}$ Dobb, M. G., Nott, J. A.. and Sikorski, J., Proe. European Conf. Eleetron Microscopy, Delft, Pt. II, 664(1980).

4 Dobb, M. G., and Sikorski, J., Colloque Structure de la Laine: Rull. Inst. Text. France, 37 (1961).

${ }^{5}$ Dobb, M. G., thesis, Univ. Leeds (1963).

\section{Time required for Tumour Initiation by Agrobacterium tumefaciens on Pinto Bean Leaves}

THE mechanism of tumorogenesis by Agrobacterium tumefaciens, the organism responsible for crown-gall tumours in plants, may be subject to critical experimental analysis in a host-pathogen complex only when the precise time during which tumour initiation occurs and the time required for the initiation of individual tumours are known. Knowledge of these time requirements and the factors influencing them may also provide insight into the number and kinds of processes involved in crown-gall tumour formation.

Tho initiation of crown-gall tumours in other host systems is romarkably sensitive to temporature ${ }^{1,2}$. The induction of normal tumours takes place at temperatures as high as $27^{\circ} \mathrm{C}$ but is completely supprossed at $32^{\circ} \mathrm{C}$. By maintaining infected plants at $32^{\circ} \mathrm{C}$ and then at $25^{\circ} \mathrm{C}$ 